UDC $930.25(477.83)$ «XIV/XVI»

DOI: doi.org/10.21272/shaj.2019.i33.p.24

TETIANAN.BILUSHCHAK

$\mathrm{PhD}$ (History), Assistant Lecturer, Lviv Polytechnic National University (Ukraine)

\title{
FUNCTIONAL ANALYSIS OF PRIVILEGES IN DOCUMENT-COMMUNICATION SYSTEM OF ROYAL CHANCELLERY OF THE JAGIELLONIAN DYNASTY LVIV DEFENSE POLICY DURING ITS PRE-SOURCE EXISTENCE (INFORMATION POTENTIAL OF ARCHIVAL FUNDS TSDIAL OF UKRAINE)
}

\begin{abstract}
The funds of the Central State Historical Archive of Ukraine in Lviv have been analyzed. It is turned out that the most significant information potential regarding the Jagiellonian dynasties Lviv defense policy is fund: 52, 131.

One of the types of documents created by the Royal Chancellery, namely privileges as a result of the activity of the document-communication system of the defense policy of Lviv of the Jagiellonian dynasty, was researched. During the document processing, privileges in the content have been systematized as those issued for the restoration of the city's defense capability, for protection against attacks by Turkish-Tatar troops and for natural disasters elimination. On the basis of them, the analysis of the functions they performed during their pre-source existence was made.

The analysis of documents in the period of its pre-source existence makes it possible to consider it as a real phenomenon, and as a fact of the historical process. Another benefit of this research is that, depending on the role that privileges have played in the past, its significance in the source base is largely determined. The more significant the primary social function of the source (the impact on subsequent historical events, processes, phenomena, breadth of scope, etc.), the more important the value of the source as the information bearer.

Thus, the following functions were clarified as informational, social, communicative, administrative, legal, and historical functions, which acquired privileges after their operational acting role and were sent to Central State Historical Archive of Ukraine in Lviv for preservation.

The paper gives examples of the Jagiellonian dynasty privileges and the dynamics of their issuance during the defense capabilities and fortifications construction enhancement in Lviv for natural disasters or enemy attack protection. The study found that the urban privileges granted by monarchs at different times were the main research source into the kings' policy to strengthen Lviv's defense capabilities.

The informative value of the sources consists of the possibility to trace the emergence of Lviv as an important defense and strategic center by analyzing the document content. The city fortifications are first mentioned in the privileges of Vladislav II Jagiello. During the reign of the successors of Vladislav II Jagiello - Casimir IV and Jan Olbracht, a large-scale construction of new fortifications, walls and towers was completed. The privileges of the successor kings Jagiel are typologically similar and granted for the same purpose as Vladislav II Jagiel himself.

Keywords: document-communication system, Jagiellonian dynasty, medieval Lviv, defense fortifications, archival sources, privileges, functional analysis.
\end{abstract}

\section{БІЛУЩАК Т.М.}

Кандидат історичних наук, Національний університет “Львівська політехніка” (Україна)

\section{ФУНКЦЙНИЙ АНАЛІЗ ПРИВІЛЕЇВ В ДОКУМЕНТНО-КОМУНІКАЦІЙНІЙ СИСТЕМІ ОБОРОННОЇ ПОЛІТИКИ М.ЛЬВІВ ДИНАСТІЇ ЯГЕЛЛОНІВ У ПЕРІОД ЙОГО ДОДЖЕРЕЛЬНОГО ІСНУВАННЯ (ІНФОРМАЦЙНИЙ ПОТЕНЦІАЛ АРХІВНИХ ФОНДІВ ЦДІАЛ УКРАЇНИ)}

Анотація. Здійснено аналіз фондів Центрального державного історичного архіву Украӥни, м.Львів (ЦДІАЛ України). Виявлено, щзо до найбільш значних за інформаційним потенціалом щзодо оборонної політики династї̈ Ягеллонів належать: ф.52, 131. 
Досліджено один із видів документів, створених в королівській канцелярї, а саме привілеї як результат діяльності документно-комунікаційної системи оборонної політики м. Львів династії Ягеллонів. На основі їх здійснено аналіз функиій, які вони виконували у період їхнього доджерельного існування. 3'ясовано наступні функиії: інформаційну, соціальну, комунікативну, управлінську, правову, а також історичну, яких набули привілеї після своєї оперативної дієвої ролі і були відправленні до ЦДІАЛ України на збереження.

Під час опраџювання систематизовано привілеї за їх змістом як такі, щзо були видані для відновлення обороноздатності міста, для захисту від нападів турецькотатарських військ та від усунення природних катаклізм. В роботі наведено приклади привілеїв династії Ягеллонів та динаміку їх видачі. У результаті проведеного дослідження встановлено, що міські привілеї, надані монархами у різні часи, є основним джерелом дослідження політики королів щзодо зміцнення обороноздатності Львова. А також 3 аналізу змісту королівських привілеїв можна прослідкувати становлення Львова як важливого оборонно-стратегічного центру. Міські укріплення вперше згадуються у привілеях Владислава II Ягайла. За правління наступників Владислава II Ягайла Казимира IV і Яна Ольбрахта завершувалось масштабне зведення нових укріплень, мурів та веж. Привілеї королів-наступників Ягайла типологічно схожі і надавались з иією ж самою метою, щчо й самим Владиславом II Ягайлом.

Ключові слова: документно-комунікаційна система, династія Ягеллонів, середньовічний Львів, оборонні укріплення, архівні джерела, привілеї, функційний аналіз.

БИЛУЩАК Т.Н.

Кандидат исторических наук, Национальный университет “Львовская политехника” (Украина)

\section{ФУНКЦИОНАЛЬНЫЙ АНАЛИЗ ПРИВИЛЕГИЙ В ДОКУМЕНТНО- КОММУНИКАЦИОННОЙ СИСТЕМЕ ОБОРОННОЙ ПОЛИТИКИ г.ЛЬВОВ ДИНАСТИИ ЯГЕЛЛОНОВ В ПЕРИОД ЕГО ДОИСТОЧНИКОВОГО СУЩЕСТВОВАНИЯ (ИНФОРМАЦИОННЫЙ ПОТЕНЦИАЛ АРХИВНЫХ ФОНДОВ ЦГИАЛ УКРАИНЫ)}

Аннотация. Осуществлен анализ фондов Центрального государственного исторического архива Украины во Львове (ЦГИАЛ Украины). Выявлено, что к наиболее значительным по информационному потенциалу по оборонной политикединастии Ягеллонов принадлежат: ф. 52, 131.

Исследован один из видов документов, созданных в королевской канцелярии, а именно, привилегии как результат деятельности документо-коммуникационной системы оборонной политики г.Львов династии Ягеллонов. На основе их осущцествлен анализ функций, которые они выполняли в период их до исходного источника существования. Определены следующчие функции: информаџчонная, социильная, коммуникативная, управленческая, правовая, а также историческая, которые получили привилегии после своей оперативной действенной роли и были отправлень в ЦГИАЛ Украинь на хранение.

Во время обработки систематизировань привилегии по их содержанию как такие, которые были вылданы с иелью восстановления обороноспособности города, для зашиты от нападений турецко-татарских войск и от устранения природных катаклизмов. В работе приведены примеры привилегий династии Ягеллонов и динамика их выдачи. В результате проведенного исследования установлено, что городские привилегии, предоставленные монархами в разное время, являются основным источником исследования политики королей по укреплению обороноспособности Львова. А также из анализа содержания королевских привилегий можно проследить становление Львова как важного оборонно-стратегического иентра. Городские укрепления впервые упоминаются в привилегиях Владислава II Ягайло. В правление преемников Владислава II Ягайло - Казимира IV и Яна Ольбрахта закончилось масштабное строительство новых 
укреплений, стен и башен. Привилегии королей-преемников Ягайло типологически схожи и предоставлялись с этой же иелью, что и самим Владиславом II Ягайло.

Ключевые слова: документо-коммуникачионная система, династия Ягеллонов, средневековый Львов, оборонительные укрепления, архивные источники, привилегии, функииональный анализ.

Згадування Львова як військово-оборонного центру посідало вагоме місце в документній комунікації різних монархів Польської Корони, а згодом Речі Посполитої. Від королівської влади залежало, аби місто було добре укріпленим і у разі нападу ворога могло витримати облогу. Міські привілеї, надані монархами у різні часи, є основним джерелом дослідження політики королів щодо зміцнення обороноздатності міста Львова (Bilushchak, 2013; Білущак, Шеломенцев-Терський, 2013). Актуальність теми зумовлюється вивченням структури інформації привілеїв, наданих династією Ягеллонів, що дадуть змогу простежити, якими функціями володів документ і з якою метою створювався. Це дозволить вибудувати інформаційний процес, який відбувався в стінах міста Львова в час його створення та доджерельного існування.

На основі вищезазначеного можна сформувати мету дослідження, яка полягає у визначенні інформаційного потенціалу фондів Центрального державного історичного архіву України м.Львів (ЦДІАЛ України) та у проведенні аналізу, розкритті функцій привілеїв, які вони виконували у період доджерельного існування в системі документної комунікації династії Ягеллонів щодо питань обороноздатності міста Львова. Для досягнення мети необхідно виконати такі завдання: проаналізувати наявні дослідження у галузі обороноздатності Львова; провести аналіз наукових праць 3 дослідження функцій документів; здійснити функційний аналіз королівських привілеїв.

Вагомим внеском у вивчення теми, яка містить послідовний аналіз подій у Львові від XIV до XVIII ст., є праця Діонісія Зубрицького (Zubrzycki, 1844). Дослідження обороноздатності укріплень міста Львова аналізував на підставі документів і львівський історик XIX ст. А. Чоловський (Czoiowski, 1910, 1896 ). Зокрема, варто відзначити наукову працю польського дослідника В. Томкевича, який грунтовно дослідив розвиток оборонного будівництва Львова (Zimorowicz, 1899). На сьогодні привілеї міста Львова опубліковані у вигляді окремого видання, підготовку та упорядкування якого здійснили М.Капраль, Я.Дашкевич та Р.Шуст (Капраль та ін., 2010).

Для 3'ясування функцій привілеїв розглянуто наукові праці українських та зарубіжних вчених, які вивчали та визначили головні, загальні та спеціальні функції документів, зокрема, В. Банасюкевича, М. Ілюшенка, В. Кашепова, С. Кулешова, Н. Кушнаренко, М. Ларькова, К. Мітяєва, Є. Плешкевича, А. Сокової, В. Стрельського, Г. Швецової-Водки.

Грунтовне дослідження класифікації функцій документа було також зроблено М. Ілюшенком, де класифікація відбувається з позицій комплексності функцій документа (Илюшенко, 1973). За твердженнями М. Ілюшенка, один документ може поєднувати різні функції і виділити їх можна тільки умовно - теоретично, що дає можливості зручної класифікації та аналізу. Класифікація залежить від певних критеріїв, за котрими іiі здійснюють, тому цінним $є$ те, що, вивчаючи функції документа, потрібно опиратися на його зміст. Вагомий внесок у дослідження функцій документа внесла Н. Кушнаренко, яка виділила головну, загальну та спеціальну функції, які вважає соціальними (Кушнаренко, 2008). Проте, функційний аналіз документної комунікації оборонної політики міста Львова у період його доджерельного існування ще не вивчався і має особливу інформаційну цінність для історичних розвідок. 
Розглянемо роль та функції привілеїв у системі соціальних комунікацій оборонної політики Львова династії Ягеллонів. Час правління Владислава II Ягайла став сприятливим як для розвитку міста, так і для значного покращення його укріплень. Модернізації міста сприяла низка привілеїв, наданих його жителям - право складу, земельні надання (Tomkiewicz, 1971: 98). Однак, королівські привілеї дозволяють простежити формування Львова як провідного оборонно-стратегічного центру. Львівські фортифікації вперше згадуються у привілеях Владислава II Ягайла. Метою фіксації привілею у королівській канцелярії від 29 вересня 1388 р. послугувало рішення покращити стан мурів. Для цього львівській війт мав відступити кожний третій денарій від своїх доходів (Капраль та ін., 2010: 51-52). Ще одним стратегічним рішенням Владислава II Ягайла щодо покращення обороноздатності міста був привілей від 18 вересня 1415 p., де містилася інформація про розширення земельних володінь міщан, зобов'язання їх ремонтувати будівлі мурів та оборонні споруди і постійно посилювати їх “для зручності держави" (Капраль та ін., 2010: 62-64).

За правління наступників Владислава II Ягайла - Владислава III Варненчика, Казимира IV і Яна Ольбрахта завершувалось грандіозне спорудження нових укріплень, мурів та веж (Tomkiewicz,1971: 100). Привілеї королів-наступників Владислава II Ягайла типологічно схожі і надавались 3 тією ж самою метою, що й самим Ягайлом. Наприклад, привілеєм від 29 серпня 1447 р. Львову щорічно виділялось 20 гривень 3 львівських королівських мит для утримання в кращому стані міських фортифікацій (Капраль та ін., 2010: 104-105).

В зв'язку із зовнішньополітичними чинниками, починаючи з середини XV ст., значно посилюється роль Львова як оборонного центру. Інформаційний потенціал у вивченні обороноздатності Львова та причини виникнення документної комунікації простежуємо в наступних привілеях династії Ягеллонів (Liske, 1878; ЦДІАЛ. Ф. 52. Оп. 2. Спр. 642; ЦДІАЛ. Ф. 131. Оп. 1. Спр. 220, 224, 231, 238, 249, 275, 281). Простежимо динаміку видачі привілеїв на звільнення від податків, мит задля будівництва укріплень 3 королівської канцелярії Казимира IV, Яна I Ольбрахта, Олександра Ягеллончика, Сигізмунд I Старого поданої у таблиці 1.

Таблиця 1. Динаміка видачі привілеїв з королівської канцелярії на звільнення від податків, мит для будівництва оборонних укріплень

\begin{tabular}{|c|c|}
\hline \multicolumn{2}{|r|}{ Ким видано прив ілей } \\
\hline & Казимир IV \\
\hline Дата привілею & Короткий зміст привілею \\
\hline 21 cep & $\begin{array}{l}\text { Звільнення жителів міста Львова на } 8 \text { років від податків та } \\
\text { контрибуцій задля укріплення оборонних мурів та валів. }\end{array}$ \\
\hline 2 липня 1479 р. & $\begin{array}{l}\text { Продовжується звільнення від податків на } 2 \text { роки, враховуючи } \\
\text { попередні } 8 \text { років для будівництва оборонних укріплень для міста. }\end{array}$ \\
\hline 17 лютого 1484 р. & $\begin{array}{l}\text { Для завершення мешканцями Львова оборонних укріплень для } \\
\text { підвищення мотивації до роботи додається звільнення від податків } \\
\text { ще } 6 \text { років. }\end{array}$ \\
\hline 28 січн я 1487 p. & $\begin{array}{l}\text { Король поступається містові податком, що зветься циза, на } \\
\text { відбудову міста. }\end{array}$ \\
\hline 28 січн я 1487 p. & $\begin{array}{l}\text { Король дає право бурмистрові та львівським райцям ще } 2 \text { роки } \\
\text { після останнього звільнення збирати податки лише на відновлення } \\
\text { міста. }\end{array}$ \\
\hline
\end{tabular}




\begin{tabular}{|c|c|}
\hline 16 квітня 1489 р. & $\begin{array}{l}3 \text { метою направлення коштів на фортифікацію міста король } \\
\text { проголошує, що позбавляє мешканців Львова на } 1 \text { рік від сплати } \\
\text { будь-яких податків. }\end{array}$ \\
\hline 7 грудня 1490 р. & 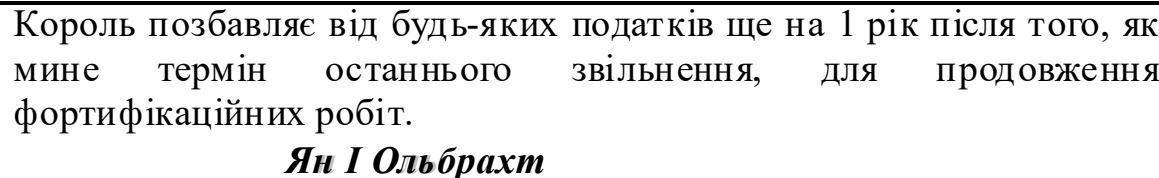 \\
\hline 8 лютого 1493 р. & $\begin{array}{l}\text { Король надає Львову звільнення від усяких податків протягом } 4 \\
\text { років після закінчення терміну попереднього звільнення, наданого } \\
\text { Казимиром IV, для продовження фортифікації міста. }\end{array}$ \\
\hline 25 січня 1494 р. & $\begin{array}{l}\text { Король, зважаючи на чималу шкоду, спричинену Львову пожежею, } \\
\text { позбавляє на } 15 \text { років від нового міського податку тих, які } \\
\text { безпосередньо зазнали втрат від пожежі, і на десять років - всіх } \\
\text { інших, щоб дати їм можливість відбудувати будинки, вежі та інші } \\
\text { укріплення, знищені пожежею. }\end{array}$ \\
\hline 20 червня 1497 p. & $\begin{array}{l}3 \text { метою укріпити фортифікації міста король позбавляє львівських } \\
\text { мешканців від недавно встановленого мита. }\end{array}$ \\
\hline 18 квітня 1499 р. & $\begin{array}{l}\text { Король у зв'язку з нападом турків і татар позбавляє львівських } \\
\text { міщан на } 15 \text { років від сплати будь-яких мит від товарів у цілому } \\
\text { Польському королівстві. } \\
\text { олександр Ягеллончик }\end{array}$ \\
\hline 22 травня 1505 р. & $\begin{array}{l}\text { Король, щоб заохотити львівських громадян укріплювати місто, } \\
\text { позбавляє львів’ян та купців від сплати перевізного, мостового та } \\
\text { гребельного мит в усій державі, зрівнюючи у цьому відношенні } \\
\text { Львів з Краковом. } \\
\text { Король позбавляє місто Львів від сплати шосу на } 1 \text { рік, а чопового - } \\
\text { на } 2 \text { квартали. }\end{array}$ \\
\hline 22 лютого 1506 р. & $\begin{array}{l}\text { Король позбавляє львівських міщан від сплати } \\
\text { цивільних податків і чопового протягом } 6 \text { років. }\end{array}$ \\
\hline & Сихізмунд I Старий \\
\hline 17 лютого 1507 p. & $\begin{array}{l}\text { Король позбавляє Львів від всіх міських податків і чопового на } 6 \\
\text { років. }\end{array}$ \\
\hline 18 грудня 1512 p. & $\begin{array}{l}\text { Король з метою відбудови міста позбавляє Львів від сплати шосу } \\
\text { на } 1 \text { рік, а чопового - на } 2 \text { квартали. }\end{array}$ \\
\hline 26 вересня 1515 р. & $\begin{array}{l}\text { Король позбавляє місто Львів від сплати чопового податку на } 2 \\
\text { квартали. }\end{array}$ \\
\hline 6 березня 1517 p. & $\begin{array}{l}\text { Король позбавляє місто Львів від сплати чопового на два квартали } \\
\text { та шосу на } 1 \text { рік. }\end{array}$ \\
\hline 17 березня 1518 р. & $\begin{array}{l}\text { Король позбавляє місто Львів від сплати шосу і чопового на } 2 \\
\text { квартали. }\end{array}$ \\
\hline $1521-1523$ pp. & $\begin{array}{l}\text { Король позбавляє місто Львів від податків на користь посилення } \\
\text { його обороноздатності. }\end{array}$ \\
\hline $1525-1547$ pp. & $\begin{array}{l}\text { Король позбавляє місто Львів від податків на користь посилення } \\
\text { його обороноздатності. }\end{array}$ \\
\hline
\end{tabular}

Видання королівських привілеїв на звільнення від сплати мит, податків зумовлювалися не лише потребою в посиленні обороноздатності міста, але й здійснювались унаслідок спустошливих татарських нападів та від усунення природних катаклізмів, яких нерідко зазнавало місто. Наприклад, такі привілеї видав Ян Ольбрахт для міщан у 1499 р., який у зв'язку з нападом турків і татар звільнив 
львівських міщан на 15 років від сплати будь-яких мит від товарів та в 1494 р. звільнив на 15 років від нового податку тих, хто безпосередньо зазнав збитків від пожежі. (Капраль та ін., 2010: 142-145).

Варто зазначити, що однією з обтяжливих форм оподаткування населення окрім сплати мит та податків на користь королівської казни були збори на утримання війська, його квартирування, а також грошові відрахування на королівське військо. Тут можна простежити окрему категорію королівських привілеїв, які приймалися для звільнення від цих поборів. Наприклад, зареєстрований привілей від 18 жовтня 1496 р. виданий Яном Ольбрахтом, в якому він позбавляв райців і всю громаду Львова від обов'язку постачання одного воєнного воза у похід (Капраль та ін., 2010: 136-137). До цієї ж групи привілеїв відносяться привілеї-звільнення від участі у військових походах (привілей-звільнення від молдавського походу Сигізмунда I у 1509 р.) (Капраль та ін., 2010: 168-169).

Король Сигізмунд I Старий, як і його попередники, продовжив політику зменшення податкового тиску на львів'ян з метою пришвидшення будівництва та зведення міських укріплень. Серед іншого, привертає увагу привілей короля, виданий 17 лютого 1525 p., згідно з яким Сигізмунд дозволяв бурмистру і райцям Львова збирати у час ворожих нападів по півгроша або дев'ять денарів від кожного возу приїжджих людей з метою наведення порядку та відбудови й укріплення міста (Капраль та ін., 2010: 185-188). Мотивом надання привілею було те, що в час військової загрози, зокрема татарських нападів, Львів ставав притулком для населення із довколишніх сіл і містечок та біженців із ближніх регіонів. Все це створювало надмірне навантаження на інфраструктуру та комунікації міста, які опісля непросто було повернути до нормального стану. 3 іншого боку, привілей визначає особливе місце Львова як ключового оборонного форпосту регіону, що сприймався місцевим населенням як найбільш безпечний. Відтак привілей зробив цю безпеку оплачуваною послугою міста.

Як уже згадувалося, привілеї видавалися не лише для сприяння посилення обороноздатності міста, але і для ліквідацій природних катаклізмів, яких нерідко зазнавало місто. Так, унаслідок пожежі наприкінці XV ст. згоріло кілька веж, а через повінь 1514 р. течією Полтви знесло цілий вал (Tomkiewicz, 1971: 102,104). Найбільша пожежа в історії міста, яка завдала масштабної шкоди Львову, була зафіксована у 1527 р. Під час вибуху міських арсеналів серйозних руйнувань зазнали мури і вежі міста. В цілому, протягом 1380-1734 pр. місто горіло 14 разів (Tomkiewicz, 1971: 105). Внаслідок руйнування міста через природні катастрофи, які вносили свої корективи у міцність оборонних споруд Львова, як монархи, так і магістрат знову і знову мусили шукати шляхи щодо відновлення та зміцнення укріплень міста. Низка документів була присвячена вирішенню питання відбудови львівських міських укріплень. Король Сигізмунд видає ряд привілеїв, які звільняли міщан Львова від сплати податей на двадцять років, чопового - на сім років, а також забороняє зведення будинків з дерева (Капраль та ін., 2010: 208-210). Задля відновлення міських укріплень після пагубної пожежі 1527 р. Сигізмунд віддав місту право збирати чоповий податок - на два роки у 1532 р. і на шість років у 1535 р. (Капраль та ін., 2010: 222-224).

Наступник Сигізмунда I, Сигізмунд II Август своїм привілеєм-підтвердженням від 5 квітня 1552 р. врегулював забезпечення діяльності сторожі львівських брам. Посилаючись на віддавна існуючий звичай, король підтвердив право сторожів брам збирати при в'їзді до міста від кожного воза чи саней дров, сіна і соломи по одному поліну або в'язці сіна чи соломи (Капраль та ін., 2010: 313-316).

Адміністрація Сигізмунда II Августа, як і його попередників, продовжила політику пошуку нових джерел та можливостей відновлення міських укріплень. У 1555 р. 
Сигізмунд II Август надав райцям міста Львова право використовувати на відбудову міських укріплень спадщину львівських міщан, які померли без спадкоємців. Такий крок король пояснював тим, що “жителі мають потребу у видатках, щоб вибудувати нові укріплення міста і ті, що за старістю є зношені, відновити і поновити” (Капраль та ін., 2010: 345). Отож, король безпосередньо вказував на незадовільне становище укріплень станом на середину XVI ст.

Привілеєм від 9 квітня 1565 р. Сигізмунд II спрямував чверть прибутків від шосу на потреби міста і оновлення його укріплень, решта суми щорічно мала надходити до королівського скарбу (Капраль та ін., 2010: 360-362). Загалом Сигізмунд II Август, у порівнянні зі своїми попередниками видав найменшу кількість привілеїв, які б сприяли налагодженню міської обороноздатності, відновленню та зведенню нових укріплень. Все це вказує на те, що будівництво нових укріплень в часи правління Сигізмунда II Августа припинилося, а відновлення вже існуючого оборонного комплексу занедбалося. Чимало привілеїв короля $є$ підтвердженнями привілеїв наданих його попередниками. Так, декретом від 28 травня 1569 р. Сигізмунд II Август зберіг за львівськими міщанами привілей Владислава III, який звільняв їх від всяких оплат на підводи, незважаючи на те, що згідно з однією із сеймових конституцій такі привілеї для усіх міст в державі уже були скасовані. Король у своєму декреті наголошував, що “оскільки місто Львів близько кордонів королівства знаходиться і $є$ виставлене через це на небезпеку від ворогів і частих нападів, для попередження і відсічі яких, як передбачається, є необхідні великі кошти i видатки" (Капраль та ін., 2010: 365-367). Цікаво, що підставою видачі привілею були перипетії, викликані судовою тяганиною між міщанами і королівською адміністрацією, яка вимагала сплати податку на підводи аж за три роки - стільки часу пройшло з моменту скасування звільнення на його оплату. Король, аби вберегти лояльність міщан, вирішив звільнити їх як від майбутніх оплат так і від сплати заборгованої суми.

Уже на схилі свого правління Сигізмунд II Август у 1571 р. надав місту привілей, за яким відступив на шість років Львову чопове з метою використання доходів 3 цього податку для відбудови башт, воєнних знарядь та інших укріплень, знищених пожежею (Капраль та ін., 2010: 368-367). Причиною видачі привілею стала пожежа, яка виникла у Львові у 1571 р. та знищила східну частину середмістя разом з Успенською церквою (Zubrzycki, 1844: 194). Як зазначено у привілеї, внаслідок пожежі особливо значних руйнувань зазнали міські укріплення. 3 тою ж метою король надав міщанам привілей, за яким дозволяв будувати у Львові хлібні ятки на площі Ринок чи в інших місцях і віддав річний чинш з цих яток львівським міщанам на відбудову й укріплення міста з умовою, що бурмистр та райці щорічно складатимуть рахунок з використаних коштів (вказувалось у прикінцевій клаузулі документа) (Капраль та ін., 2010: 370-371).

Одним із аспектів спільної взаємодії королівської влади і магістрату Львова було використання міської артилерії на військові потреби армії. Артилерія Львова залучалася в ході польсько-молдавських чи польсько-турецьких воєн. Після військових кампаній, особливо якщо вони не були успішними, львівські гармати не завжди поверталися на місце свого дислокування. Підставою для використання львівської артилерії поза межами міста слугували відповідні королівські декрети та листи. Наприклад, 12 березня 1570 p. Сигізмунд II Август звернувся до львівського магістрату з проханням, щоб місто надало для військового походу 12 фальконетів з порохом, кулями та іншою необхідною амуніцією (ЦДІАЛ. Ф. 52. Оп. 1. Спр. 42: 32). Використання львівської артилерії не лише для потреб міста мало місце не тільки під час війн. Так, у 1554 р. Сигізмунд II Август у своєму листі, датованому 12 квітня наказав, аби городоцькому старості Миколаю Мелецькому для Городоцького замку видали дві великі гармати, оскільки “потреба того, щоб Городоцький замок був забезпечений артилерією” (ЦДІАЛ. Ф. 52. Оп. 1. Спр. 42: 30). 
В контексті історико-архівних студій визначено джерельно-інформаційний потенціал привілеїв створених династією Ягеллонів щодо питань обороноздатності міста Львів. Таким чином, проаналізувавши привілеї, які функціонували у документнокомунікаційній системі династії Ягеллонів в питанні обороноздатності міста Львова можемо систематизувати їх за змістом як привілеї, що були видані для відновлення обороноздатності міста, для захисту від нападів турецько-татарських військ та від усунення природних катаклізмів. 3 проаналізованих привілеїв XIV-XVI ст. виданих династією Ягеллонів щодо оборонної політики міста Львів можемо виділити наступні функції: інформаційну оскільки, привілеї створювалися з певних причин задля фіксування інформації; соціальну, адже кожний виданий привілей династії Ягеллонів був спричинений певною соціальною потребою; комунікативну, що виконувала функцію засобу зв'язку між окремими елементами суспільної структури. До специфічних функцій документа належать: управлінська, що виконувала функцію реалізації завдань та рішень, які виходили з королівської канцелярії; правова, оскільки, видані привілеї були засобом закріплення і змін правових відносин під час посилення обороноздатності чи будівництва фортифікацій у Львові під час стихійних лих чи ворожих нападів; а також історична функція, яку набули привілеї після своєї оперативної дієвої ролі і були відправлені до ЦДІАЛ України на збереження.

\section{Література:}

Банасюкевич, 1973 - Банасюкевич В. Функции управленческих документов // Терминологические проблемы в области документоведения и архивоведения: тези сообщений к теоретическому семинару. ВНИИДАД. 1973. С. 69-75.

Білущак, 2016 - Білущзак T. Роль документів в інформаційній комунікації міської влади у питаннях розбудови та налагодження оборони міста Львова у першій половині XVII ст. (на прикладі архівних джерел ЦДІА України у м. Львів) // ЕМІНАК: науковий щоквартальник. 2016. № 2 (1). Т.1. С. 10-16.

Білущак, Шеломенцев-Терський, 2013 - Білущак Т., Шеломенцев-Терський С. Стан обороноздатності Львова у світлі архівних документів королівської канцелярії середини XIV - середини XVII ст. // Студії 3 архівної справи та документознавства. 2013. Т. 21. С. 140-147.

ЦДІАЛ України - Центральний державний історичний архів України, м.Львів.

Кушнаренко, 2008 - Кушнаренко Н. Документоведение: учеб. 8- изд., стер. К.: Знання, 2008. 459 с.

Илюшенко, 1973 - Илюшенко М. К вопросу о функциях документов // Советские архивы. 1973. № 5. C. 10-17.

Капраль та ін., 2010 - Капраль М., Дашкевич Я., Дашкевич Р. Привілеї міста Львова (XIV-XVIII ст.). Львів: Львівське відділення Інституту української археографії та джерелознавства ім. М.Грушевського НАН України; Львівський національний універсистет ім. І.Франка, 2010. 544 с.

Liske, 1878 - Liske X. Akta grodzkie i ziemskie z czasyw Rzeczypospolitej Polskiej z archiwum tak zwanego bernardycskiego we Lwowie. Lwyw: Z Drukarni zakiadu narodowego im. Ossolicskich, 1878. $326 \mathrm{~s}$.

Bilushchak, 2013 - Bilushchak T. Documents Central State Historical Archives in Lviv as a Channel of Social Communication // Proceedings 4th International Academic Conference of Young Scientists "Humanities and Social Sciences 2013". Lviv, 2013. Electronic edition on CD-ROM. P. 100 -102.

Tomkiewicz, 1971 - Tomkiewicz W. Dzieje obwarowac miejskich Lwowa // Kwartalnik architektury i urbanistyki. Teoria i historia. Warszawa, 1971. T. XVI. S. 93-138.

Zimorowicz, 1899 - Zimorowicz B. Leopolis Triplex czyli Kronika miasta Lwowa // Opera quibus res gestae urbis Leopolis illustrantur ex mandato senatus eiusdem civitatis Leopoli, 1899. 424 p.

Zubrzycki, 1844 - Zubrzycki D. Kronika miasta Lwowa. Lwyw, 1844. 600 s.

Czoiowski, 1896 - Czoiowski A. Pogląd na organizacyę i działalność dawnych władz miejskich do 1848 r. / / Miasto Lwów w okresie samorządu (1870-1895). Lwyw: Gmina, 1896. S. XXIII-LXXXIV. 1910. $126 \mathrm{~s}$.

Czoiowski, 1910 - Czołowski A. Wysoki Zamek. Lwów: Towarzystwa Miłośnikow Przeszłości Lwowa,

\section{References:}

Banasyukevich, 1973 - Banasyukevich $V$. Funktsii upravlencheskikh dokumentov [The management document functions] // Terminologicheskie problemy v oblasti dokumentovedeniya i arkhivovedeniya: tezi soobshchenii k teoreticheskomu seminaru. VNIIDAD. 1973. S. 69-75. [in Russian].

Bilushchak, 2016 - Bilushchak T. Rol' dokumentiv v informacijnij komunikacii' mis'koi' vlady u pytannjah rozbudovy ta nalagodzhennja oborony mista L'vova u pershij polovyni XVII st. (na prykladi arhivnyh dzherel CDIA Ukrai'ny u m. L'viv) [The role of documents in information communications 
of the city authorities in matters of development and defense adjustment of Lviv city during the first half XVII century (on the example archival sources of CSHA of Ukraine in Lviv)] // EMINAK: naukovyj shhokvartal'nyk. 2016. № 2 (1). T.1. S. 10-16. [in Ukrainian].

Bilushchak, Shelomencev-Ters'kyj, 2013 - Bilushchak T., Shelomencev-Ters 'kyj S. Stan oboronozdatnosti L'vova u svitli arhivnyh dokumentiv korolivs'koi' kanceljarii' seredyny XIV - seredyny XVII st. [Defense capacity based on archival documents of the Royal Chancellery in mid XIV-XVII centuries] // Studii' z arhivnoi' spravy ta dokumentoznavstva. 2013. T. 21. S. 140-147. [in Ukrainian].

TsDIAL Ukrai'ny - Tsentralnyi derzhavnyi istorychnyi arkhiv Ukrainy m.Lviv [Central State Historical Archives of Ukraine in Lviv]. [in Ukrainian].

Kushnarenko, 2008 - Kushnarenko N. Dokumentovedenie[Documentary science]: ucheb. 8- izd., ster. K.: Znannya, 2008. 459 s. [in Russian].

Ilyushenko, 1973 - Ilyushenko M. K voprosu o funktsiyakh dokumentov [To the issue of document functions] // Sovetskie arkhivy. 1973. № 5. S. 10-17. [in Russian].

Kapral' ta in., 2010 - Kapral'M., Dashkevych Ja., Dashkevych R. Pryvilei' mista L'vova (XIV-XVIII st.) [Privileges of Lviv (XIV-XVIII centuries)]. L'viv: L'vivs'ke viddilennja Instytutu ukrai'ns'koi' arheografii' ta dzhereloznavstva im. M.Grushevs'kogo NAN Ukrai'ny; L'vivs'kyj nacional'nyj universystet im. I.Franka, 2010. 544 s. [in Ukrainian].

Liske, 1878 - Liske X. Akta grodzkie i ziemskie z czasyw Rzeczypospolitej Polskiej z archiwum tak zwanego bernardycskiego we Lwowie [Town and land files from the times of the Republic of Poland from the archives of the so-called Bernardine in Lviv]. Lwyw: Z Drukarni zakiadu narodowego im. Ossolicskich, 1878. 326 s. [in Poland].

Bilushchak, 2013 - Bilushchak T. Documents Central State Historical Archives in Lviv as a Channel of Social Communication // Proceedings 4th International Academic Conference of Young Scientists "Humanities and Social Sciences 2013”. Lviv, 2013. Electronic edition on CD-ROM. P. 100 -102. [in English].

Tomkiewicz, 1971 - Tomkiewicz W. Dzieje obwarowac miejskich Lwowa [History of the city walls of Lviv] // Kwartalnik architektury i urbanistyki. Teoria i historia. Warszawa, 1971. T. XVI. S. 93-138. [in Poland].

Zimorowicz, 1899 - Zimorowicz B. Leopolis Triplex czyli Kronika miasta Lwowa [Leopolis Triplex or Annals of the city of Lviv] // Opera quibus res gestae urbis Leopolis illustrantur ex mandato senatus eiusdem civitatis Leopoli, 1899.424 p. [in Poland].

Zubrzycki, 1844 - Zubrzycki D. Kronika miasta Lwowa [Chronicle of the city of Lviv]. Lwyw, 1844. 600 s. [in Poland].

Czoiowski, 1896 - Czołowski A. Pogląd na organizację i działalność dawnych władz miejskich do 1848 r. [A look at the organization and activities of the former municipal authorities until 1848.] // Miasto Lwów w okresie samorządu (1870-1895). Lwów: Gmina, 1896. S. XXIII-LXXXIV. [in Poland].

Czoiowski, 1910 - Czoiowski A. Wysoki Zamek [High Castle]. Lwyw: Towarzystwa Miłośnikow Przeszłości Lwowa, 1910. 126 s. [in Poland].

Отримано 2.11.2019 